\author{
Wojciech Stelmach \\ Uniwersytet im. Adama Mickiewicza w Poznaniu \\ Instytut Filologii Polskiej \\ ORCID: 0000-0003-4841-140X
}

\title{
Język tekstu z kodeksu w zbiorach Biblioteki Jagiellońskiej (sygnatura Cim. 769)*
}

\begin{abstract}
A bstrakt: Przedmiotem artykułu jest charakterystyka języka tekstu z kodeksu znajdującego się w zbiorach Biblioteki Jagiellońskiej (sygn. Cim.769). Kodeks zawiera niekompletne wydanie Historyi barzo cudnej o stworzeniu nieba i ziemie autorstwa Krzysztofa Pussmana, datowane na czas po 1551 roku. Przekład ten poddano analizie porównawczej z jego prawdopodobnym źródłem łacińskim. W artykule zamieszczono wyniki analiz językowych wybranych fragmentów edycji, a szczególną uwagę poświęcono sposobom przekładania tekstu. Pozwoliło to wskazać cechy charakterystyczne druku, a także na odniesienie ich do niektórych wniosków wynikających z pracy nad wydaniem z 1551 .
\end{abstract}

Słow a klucze: Historyja barzo cudna o stworzeniu nieba i ziemie; De creatione Adae et formatione Evae ex costa eius; przekład staropolski; apokryf; Cim.769

* Niniejszy artykuł jest wynikiem badań nad językiem religijnym w okresie staropolskim, które realizuję jako doktorant-stypendysta w grancie Narodowego Centrum Nauki nr 2017/26/E/HS2/000083: Początki języka polskiego i kultury religijnej $w$ świetle średniowiecznych apokryfów Nowego Testamentu. Uniwersalne narzędzie do badań polskich tekstów apokryficznych, którego kierownikiem jest prof. UAM dr hab. Dorota Rojszczak-Robińska. 
Historia barzo cudna i ku wiedzeniu potrzebna o stworzeniu nieba i ziemie, i inszych wszytkich rzeczy, ktore i żywa na świecie. I jako potym Pan Bog człowieka, to jest Jadama, i Jewę z kości jego stworzyt a jako żywota swego na tym świecie dokonali etc. teraz nowo na polskie z pilnościa wyłożona ${ }^{l}$ jest staropolskim apokryfem Starego Testamentu. Jego autorem jest krakowianin Krzysztof Pussman, wydawcą zaś Hieronim Scharffenberg. Tekst jest przekładem-kompilacją łacińskiej Księgi Rodzaju (jej czterech rozdziałów) i łacińskiego apokryfu De creatione Adae et formatione Evae ex costa eius. Et quomodo decepti fuerunt a serpente ${ }^{2}$ (więcej o źródłach zob. Dobrzycki 1911: 288; Adamczyk 1980: 23-24; Cały świat nie pomieścitby ksiag 1996: 91; Stelmach 2020). Do naszych czasów zachowały się dwa egzemplarze staropolskiego tekstu: II wydania z 1551 roku (obecnie w zbiorach Biblioteki Kórnickiej PAN, sygn. CIM.O.450) ${ }^{3}$ oraz edycji z pewnością XVI-wiecznej, ale powstałej po roku 1551 (w Bibliotece Jagiellońskiej, sygn. Cim.769)4 ${ }^{4}$ Pierwodruk natomiast ukazał się w 1543 roku, o czym dowiadujemy się z noty dedykacyjnej do drugiego wydania (1551: k. A3r).

Omawiany utwór jak dotąd był wydany krytycznie tylko raz przez Zygmunta Celichowskiego (1890). Edytor skolacjonował teksty obu zachowanych egzemplarzy. Transkrypcję poprzedził krótkim wstępem kodykologicznym, w którym omówił cechy fizyczne i zawartość obu kodeksów, a także odtworzył historię tekstu, opierając się na wiadomościach zaczerpniętych od bibliografów, w tym od Karola Estreichera (Celichowski 1890: 4-6). Dzięki temu dowiadujemy się, że w XVIII wieku w dwóch oficynach przynajmniej trzykrotnie powielano Historyję barzo cudna (Celichowski 1890: 6). Dlaczego zatem do naszych czasów zachowały się jedynie dwa egzemplarze, w dodatku niekompletne? Jednym z powodów, podawanym przez Celichowskiego, może być bardzo duża popularność utworu, w związku z czym był zaczytywany aż do zniszczenia całego nakładu (Celichowski 1890: 5-6). Natomiast Maria Adamczyk we wstępie do antologii Cały świat nie pomieściłby ksiag. Staropolskie opowieści i przekazy apokryficzne zwróciła uwagę na jeszcze jedną możliwość - połowa XVI wieku to okres rozpoczęcia działań kontrreformacyjnych w Kościele katolickim i zmiany stosunku do apo-

1 Dalej: Historyja barzo cudna.

2 Dalej: De creatione Adae.

3 Za A. Luto-Kamińską (2015: 70) przyjmuję dla tego wydania nazwę wyd. A.

4 Za A. Luto-Kamińską (2015) przyjmuję dla tego wydania nazwę wyd. B. 
kryfów (Adamczyk, Wydra, Rzepka 1996: 45-46). Oznaczało to, że teksty te straciły status pożytecznej lektury, stojącej w opozycji do szkodliwych moralnie średniowiecznych romansów (Starowieyski 2006: 33).

Historyja barzo cudna nie była dotąd obiektem badań językoznawczych. Jedynie Stanisław Dobrzycki na początku XX wieku zestawił jej fragment z niebiblijnym źródłem i pobieżnie zwrócił uwagę na wybrane cechy językowe (Dobrzycki 1899, 1911). Analizie języka wydania A i sposobowi, w jaki powstał ten przekład, poświęciłem swoją pracę magisterską (Stelmach 2020). W tym artykule natomiast pokażę wybrane cechy języka fragmentów wydania $\mathrm{B}$, we wnioskach odnosząc je do cech wydania A. W głównej mierze skoncentruję się na sposobach thumaczenia tekstu.

Przedmiotem analiz uczynię te fragmenty wyd. B, które dopełniają historię obecną w wyd. A (jako pierwszy wskazał je Celichowski 1890: 5). Treść pomieszczona w obu kodeksach zazębia się od sceny kuszenia Ewy w rzece Tygrys (karta C3r wyd. A i Cr wyd. B). Zdecydowałem się badać te teksty oddzielnie, ponieważ różnica w czasie ich wydania musiała być na tyle duża, że zauważalne są między nimi językowe odmienności. W centrum rozważań stawiam pytanie o relację przekładu do łacińskiego źródła i dokładność tłumaczenia. Nie prowadzę natomiast rozpoznania w zakresie typografii dzieła (nie licząc miejsc w druku, które są typowe dla wydania B).

De creatione Adae: (...) et omnes filii eius. Apparuis Michael ${ }^{5}$ stans ad caput Ade et dixit ad Seth: „Surge et vide”. Et vidit Seth manum domini extensam tenentem Adam. Et tradidit eum Michaeli dicens: „Sit in custodia tua usquam ad annos, donec convertam luctu eius in gaudium. Et tunc sedebit in loco illius, qui eum seduxit". Et accepit Michael sindonem et involvit corpus Ade et filii sui Abel et sepelivit eos in valle Ebron.

Historyja barzo cudna: (...) i wszyscy synowie jego. A ukazał się im Anjoł Michał, stojąc u głowy Adamowej, i rzekł do Set: „Wstań a patrz”. I ujźrzał Set rękę Bożą wyciągnioną, trzymającą Adama. I dał go Michałowi, mowiąc: „Niechaj będzie pod strażą twoją aż do lat, gdy przemienie [nie] jego płacz w wesele. Tedy będzie siedział na miejscu onego, ktoregom zrzucił z nieba dla pychy”. I wziąw-

5 Wszystkie podkreślenia w tekście moje - W.S. Służą one wskazaniu miejsc w tekście źródłowym i przekładzie, które w wyniku decyzji tłumacza różnią się od siebie. 
szy Anjoł Michał, w prześcieradło uwinął ciało Adamowe i syna jego Abla, ktorego był zabił Kaim, i pogrzebł je na gorze Ebron. ${ }^{6}$

W powyższym fragmencie Pussman oddał źródłowe imię Michael za pomocą grupy imiennej Anjot Michat (w omawianym fragmencie zrobił to dwukrotnie), tuż przy niej dodając zaimek wskazujący, za pomocą którego autor ukonkretnił, komu ukazał się anioł. Konsekwentne przekładanie tego imienia we wskazany sposób można zaobserwować w całym utworze (por. Stelmach 2020).

Pomyłką zecera można chyba nazwać dodanie w tekście słowa nie w zdaniu podrzędnym okolicznikowym czasu gdy przemienię [nie] jego płacz $w$ wesele (łac. donec convertam luctu eius in gaudium). Natomiast decyzją tłumacza można wyjaśnić zamianę miejsc składników w grupie nominalnej luctu eius - jego płacz. Jest to o tyle interesujące, że w przekładzie fragmentów Księgi Rodzaju, zastępujących apokryficzny wstęp utworu (znajdują się w wyd. A), Pussman stosował często szyk łaciński, wiernie podążając za źródłem (im dalej w tekst, tym wierniej - zob. Stelmach 2020). Odstępstwa od przywiązania do źródła widać natomiast we fragmentach tłumaczonych z łacińskiego apokryfu. Można postawić pytanie, czy zachowanie w omawianym fragmencie szyku typowego dla polszczyzny jest przejawem kształtowania się stylu religijnego, którego szyk przestawny jest jedną z cech.

W dalszym fragmencie widzimy, że Pussman przełożył łacińskie zdanie sedebit in loco illius qui eum seduxit jako będzie siedziat na miejscu onego, ktoregom zrzucił z nieba dla pychy. Inny jest podmiot w zdaniu łacińskim (wyrażony za pomocą zaimka eum, odnoszącego się do archanioła Michała), a inny w polskim - w zasadzie na podmiot w polszczyźnie wskazuje forma pierwszej osoby czasownika: zrzuciłem. Z tego wynika, że podmiotem zdania w Historyi barzo cudnej jest Bóg. Wydaje się, że ingerencja ta była potrzebna. Co prawda Lucyfer został strącony z nieba przez Michała, Bóg jednak wydatnie wspomógł swego archanioła, który przegrywał z bun-

6 Transkrypcje obu tekstów mojego autorstwa. Transkrypcję tekstu staropolskiego sporządzono w oparciu o zasady wypracowane przez zespół przygotowujący nowe transkrypcje staropolskich apokryfów Nowego Testamentu, pod kierunkiem prof. UAM dr hab. Doroty Rojszczak-Robińskiej. Zasady dostępne będą na stronie www.apocrypha.amu.edu.pl (strona w przygotowaniu). Zasady wydania tekstu łacińskiego (zob. Stelmach 2020). 
townikiem. Opis tego znajdujemy w zachowanych do naszych czasów staro-cerkiewno-słowiańskich apokryfach starotestamentalnych (por. Słowo Jana Złotoustego o tym, jak Michat zwyciężyt Satanaela [w: Minczew, Skowronek (red.) 2006: 12-25]). Faktyczne działanie sprawcze Stwórcy podkreślił Pussman w swoim przekładzie.

W końcowym fragmencie omawianego wyimka tekstu zostało dodane zdanie podrzędne przydawkowe brzmiące ktorego byt zabit Kaim. Magdalena Zowczak w książce Biblia ludowa. Interpretacje wątków biblijnych w kulturze ludowej wskazuje, że według tradycji żydowskiej i niektórych Ojców Kościoła, ojcem Kaina był Samael, najważniejszy z archaniołów, pod postacią współżyjący seksualnie z Ewą (Zowczak 2013: 96-97). Możliwe, że Pussman, który zastąpił rozdział De creatione Adae, w którym była mowa o bratobójstwie, niemal w całości czwartym rozdziałem Księgi Rodzaju (por. Stelmach 2020), znał te przekazy i, wskazując na nienaturalny charakter śmierci Abla, chciał podkreślić winę Kaina (będącego owocem grzechu).

Ostatnią zmianą wprowadzoną względem źródła jest zastąpienie w przekładzie łacińskiego vallis ('dolina' - za Słownikiem łacińsko-polskim... Sondla) słowem góra. Możliwym wyjaśnieniem tej decyzji tłumacza jest fakt, że według tradycji judaistycznej, chrześcijańskiej i muzułmańskiej groby patriarchów (Abrahama, Izaaka i Jakuba) zlokalizowane są na wzgórzu Hebron.

De creatione Adae: Et processerunt ante eum omnes virtutes angelorum, videntibus Seth, matre eius et nullo alio. Et dixerunt angeli ad eos: „Sicut vidistis, illos sepeliri sic de cetero sepelite mortuos vostros". His dictis angeli recesserunt. Seth vero, filius eius, plantavit ramum ad caput patris sui, sicut ei rogaverit Adam.

Historyja barzo cudna: I szły przed nimi wszy $<\mathrm{t}>$ kie mocy anjelskie a tego żaden nie widział, jedno Set a matka jego, Ewa. I rzekli aniołowie do nich: „Jakoście widzieli tych być pogrzebione, tak też wy potym chowajcie i pogrzebiajcie umarłe wasze". To wyrzekłszy, anjołowie zniknęli. A Set, syn jego, wszczepił onę rożdżkę u głowy ojca swego, jako go był prosił.

W powyższym fragmencie źródła dwukrotnie wykorzystano konstrukcję ablativus absolutus. Pierwszy raz w zdaniu videntibus Seth, matre eius et nullo alio. Można by ją przetłumaczyć następująco: „(...) których widzieli Set, matka jego i nikt inny”. Najprawdopodobniej Pussman wydzielił zdanie 
podrzędne jako samodzielne wypowiedzenie, przy czym oddał je za pomocą zdania złożonego „(...) a tego żaden nie widział, jedno Set a matka jego, Ewa”. Drugi raz w zdaniu his dictis angelis recesserunt. Zbudowane jest ono podrzędno-nadrzędnie, ze zdaniem podrzędnym okolicznikowym sposobu (his dictis). Można by je przełożyć następująco: ,gdy to powiedzieli, aniołowie zniknęli’. Staropolski tłumacz wykorzystał formę orzeczenia w imiesłowie przysłówkowym czynnym czasu przeszłego, tworząc następującą konstrukcję syntaktyczną: „to wyrzekłszy anjołowie, zniknęli”. O praktyce przekładania łacińskich konstrukcji absolutnych za pomocą zdań m.in. podrzędnych okolicznikowych pisali Jadwiga i Wacław Twardzikowie (1976).

Pussman łaciński czasownik sepelio przetłumaczył jako chować i pogrzebiać. Są to wyrazy notowane przez Słownik polszczyzny XVI wieku jako synonimy (SPXVI t. 3: 302, SPXVI t. 26: 126). We wcześniejszych partiach tekstu Pussman wielokrotnie wprowadzał w miejsce pojedynczych słów łacińskich synonimiczne szeregi składniowe. Jest to jedna z najwyrazistszych cech języka Historyi barzo cudnej (por. Stelmach 2020). O synonimii w tekstach staropolskich pisali m.in. Krystyna Kleszczowa i Mariusz Leńczuk (zob. np. Kleszczowa 2002: 279-287; Leńczuk 2007: 37-47; Leńczuk 2013).

De creatione Adae: Post multum vero tempus crevit in arborem magnam. Et postea inventa est a venatoribus Salomonis et sibi optata ad flumen ante palacium suum. Postea venit regina a finibus orientalibus videre sapietniam Salomonis. Et prophetavit hoc lignum omnia regna Judeorum destruere et inimicos eorundem.

Historyja barzo cudna: Po niemałym tedy czasie urosła ona rożdżka, ktorą był wszczepił u głowy ojca swego, wielkim drzewem. A potym było ono drzewo nalezione od łowcow abo myśliwcow krola Salamona, a tam $b<y>$ ło wzięto do rzeki przed jego dwor. Potym przyszła niektora krolowa z granic od wschodu słońca słuchać i widzieć mądrość Salamonowę, ktory był barzo mądry, ktora prorokowała iże przez to drzewo miały być popsowane wszytkie krolestwa żydowskie i nieprzyjaciele ich.

Pierwsze zdanie Post multum vero tempus crevit in arborem magnam zostało uzupełnione w przekładzie o podmiot ona rożdżka oraz dookreślające go zdanie podrzędne przydawkowe ktora byt wszczepit u głowy ojca swego. Tym samym do tekstu głównego został wciągnięty sparafrazowany tytuł. Miejsce wystąpienia tego wtrącenia może sugerować, że w rękopisie przy- 
gotowanym przez Pussmana do druku lub na późniejszym wydaniu (ale poprzedzającym wyd. B) zamieszczono glosę, i to dwupoziomową. Pierwsza (ona rożdżka) była glosą do czasownika urosta; kolejna (ktora byt wszczepit u głowy ojca swego) dookreślała, o którą gałązkę chodzi. Miejsc, w których do tekstu głównego najpewniej w druku została wciągnięta glosa, jest w Historyi barzo cudnej więcej.

W kolejnym zdaniu tłumacz dodał podmiot, ponieważ łaciński indicativus perfecti passivi - inventa est to forma trzeciej osoby liczby pojedynczej i mógł dotyczyć zarówno wspomnianej w staropolskim apokryfie różdżki, jak i wzmiankowanego w De creatione Adae wielkiego drzewa. Z tego względu Pussman uzgodnił podmiot tego wypowiedzenia z podmiotem zdania poprzedniego, wybierając zgodnie z tym, co było w tekście źródłowym, drzewo. Takie postepowanie tłumacza można też wyjaśniać wyżej opisanym wciągnięciem glos do tekstu głównego, które wymogło na autorze ujednoznacznienie treści.

Następnie pojedynczy wyraz łaciński videre oddano za pomocą szeregu stuchać $i$ widzieć. Dorota Rojszczak-Robińska o tym czasowniku pisze następująco: „Łacińskie videre mogło - poza podstawowym znaczeniem 'widzieć, patrzeć' - oznaczać także 'rozważać, wydawać się, mniemać, rozważyć, opiniować, czuć, poznać, doświadczyć, starać się o coś’. Być może dla staropolskich pisarzy w ogóle nie było tu różnicy zmysłów, ale określenie oznaczające po prostu postrzeganie" (Rojszczak-Robińska 2016: 96). Pussman zatem, być może dla pokazania, że poznanie łączy się z działaniem wielu zmysłów, a może z niechęci do wybierania tylko jednego znaczenia, użył w przekładzie dwóch czasowników nazywających czynności poznawania zmysłowego.

Ostatnią w tym fragmencie ingerencją w tekst podczas przekładu jest dodanie przez Pussmana zdania przydawkowego ktory byt barzo madry określającego króla Salomona. Mogła to być glosa wciągnięta do tekstu, mogło być to również wynikiem inspiracji krakowskiego tłumacza wydaną na początku lat 20. XVI wieku książką pt. Rozmowy, ktore miat krol Salomon madry z Marchottem grubym a sprośnym, a wszakoż, jako o niem powiedaja, barzo z wymownym. Jej autorem był Jan z Koszyczek, a ukazała się nakładem drukarni Hieronima Wietora. Również historią drzewa życia (wyrosłego z gałęzi wszczepionej u głowy Adamowej) mógł zainspirować się w wyniku lektury wydanego w Krakowie Żywota Pana Jezu Krysta Baltaza- 
ra Opeca. Wątek inspiracji (językowych oraz literackich) tłumaczy znanymi im dziełami zasługuje na osobne studia.

De creatione Adae: Quo audito Rex Salomon, hoc lignum in probaticam piscinam, lapidibus alligatis, mergi precepit. Ubi postmodum semper descendebat Angelus, et aquam movebat, et multi sanabantur per ipsum Christum, qui postmodum in ipso ligno suspensus erat, et in stipite arboris erat caput positum ita ut sanguis redemptoris eius, primi plasmatoris, descendit in caput.

Historyja barzo cudna: Co gdy usłyszał krol Salamon, rozkazał, aby to drzewo było wrzucone i wpuszczone w sadzawkę, nawiązawszy kamienia u niego, aby utonęło, i kazał je pogrążyć. Gdzie potym, gdy już było ono drzewo w onę sadzawkę wrzucono, tedy anjoł zstępował a ruszał onę wodę, gdzie ono drzewo było, i wiele chorych, ktorzy wstępowali w onę wodę, gdzie z rozmaitych niemocy byli uzdrowieni przez Pana Chrystusa, ktory potym na onym drzewie był zawieszon, i na końcu drzewa tego była głowa jego położona tak, iż krew odkupiciela jego, pirwszego człowieka, ktory był zgrzeszył, zstąpiła na głowę, to jest Adama.

W pierwszym zdaniu łacińskiego tekstu ponownie została użyta konstrukcja ablativus absolutus. Tym razem nie została przetłumaczona w sposób dotychczas stosowany przez Pussmana. Przetłumaczono participium perfecti passivi - mergi z wykorzystaniem imiesłowów przymiotnikowych biernych czasu przeszłego, synonimicznych i połączonych szeregowo (wrzucone $i$ wpuszczone).

Właśnie przez szereg spójnikowy wrzucone $i$ wpuszczone tłumacz oddał znaczenie słowa mergi. Co ciekawe, jak podaje Stownik łacińsko-polski... Sondla, mergo oznacza m.in.: '1) zanurzać, pogrążyć, zatapiać (voluptatibus se mergere - pogrążyć się w rozkoszach), (...) 3) pass.: utopić się, zatonąć (...)’. Staropolski tłumacz zatem nie tylko zastępuje pojedyncze słowo dwuskładnikowym połączeniem, ale wykorzystuje czasowniki o zbliżonym znaczeniu (więcej zob. Stelmach 2019). Może to świadczyć np. o tym, że nie był pewien składni tekstu łacińskiego i tego, w jaki sposób oddać napotkany szyk w swoim dziele. Możliwe też, że uznał za stosowne powtórzyć wcześniej przełożone zdanie w prostszej formie. W końcu może to być glosa naniesiona przez czytelnika albo wydawcę na jeden z nieistniejących już egzemplarzy Historyi barzo cudnej, którą do wyd. B (lub wcześniejszego) wciągnął edytor. 
Na końcu omawianego zdania dodano wypowiedzenie $i$ kazał je pograżyć, być może dla podkreślenia intencji Salomona, a może na wypadek, gdyby szereg wrzucone $i$ wpuszczone wywoływał u czytelnika wątpliwości dotyczące znaczenia tych predykatów.

Następnie kilkukrotnie uzupełniono tekst łaciński w przekładzie. W pierwszej kolejności zostało dodane wypowiedzenie gdy już było ono drzewo w onę sadzawkę wrzucono, będące zdaniem podrzędnym okolicznikowym czasu do zdania tedy anjoł zstępowat. Miało ono zapewne dookreślić czas narracji.

Później został wprowadzony kolejny dodatek od tłumacza - do grupy nominalnej wiele chorych dołączono zdanie podrzędne przydawkowe ktorzy wstępowali $w$ onę wodę, zaś do niego dodano zdanie podrzędne okolicznikowe miejsca gdzie z rozmaitych niemocy byli uzdrowieni przez Pana Chrystusa.

Twórczą pracę Pussmana $\mathrm{z}$ tekstem źródłowym widać również w warstwie leksykalno-semantycznej. Łaciński plasmator, jak podaje Sondel w swoim leksykonie, ma następujące znaczenia: '1) twórca, 2) rzeźbiarz, 3) Stwórca, 4) założyciel'. Wydaje się, że to właśnie w znaczeniu 'założyciel', 'fundator', 'ten, od którego wszystko się zaczęło' Pussman wykorzystał ten łaciński wyraz w analizowanym fragmencie. Przetłumaczył go jako pirwszy człowiek, dodając zdanie ktory był zgrzeszyt. Zapewne chciał w ten sposób przypomnieć winę Adama. Otrzymane wyrażenie jest jednak nieprecyzyjne i można rozumieć je dwojako: 1) pierwszy człowiek, czyli Adam, był zgrzeszył; 2) Adam był pierwszym człowiekiem, który zgrzeszył - przed nim nie było nikogo, kto wystąpiłby przeciw przykazaniu Bożemu.

Warto wspomnieć, że w innych tekstach apokryficznych, które traktują o Judaszu, równie często znajdują się dopowiedzenia typu „ktory ji zdradził” (Kozaryn 2000: 115). Być może w odniesieniu zarówno do Adama, jak i do Judasza, istniały w staropolszczyźnie pewne stałe frazy, konotowane przez sam fakt pojawienia się tych postaci w tekście.

Dodane na końcu rozdziału, w którym znajduje się omawiany fragment tekstu, wypowiedzenie to jest Adama zostało prawdopodobnie wprowadzone do tekstu przez wydawcę starszej redakcji. Świadczy o tym nie tylko sposób, w jaki ten dodatek włączono do tekstu (dodanie na końcu zdania, przez co zostało oddzielone od grupy imiennej, którą miało dopełnić), ale także ce- 
chy typograficzne, zwłaszcza wielkość czcionki, która posłużyła do zapisu imienia.

Rycina 1. Zapis imienia Adam w omawianym fragmencie tekstu

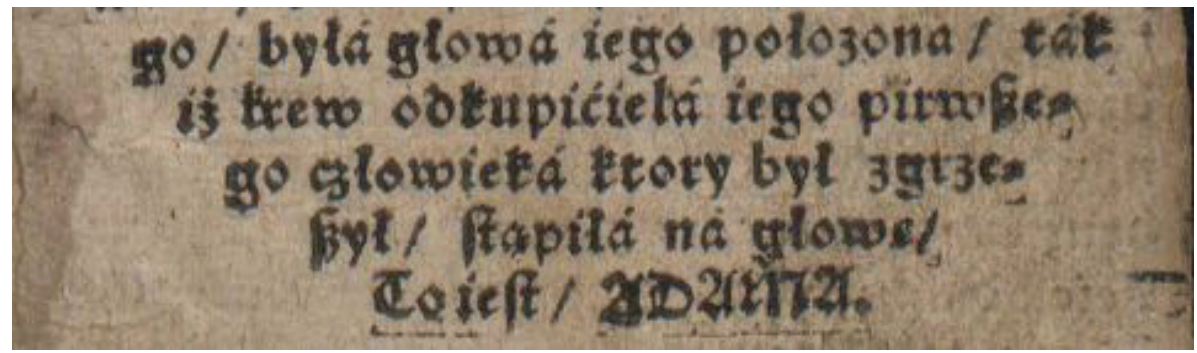

W żadnym miejscu tej edycji nie występuje zapis imienia, ani też innego wyrazu kończącego tytuł lub rozdział za pomocą kapitalików. Mamy prawdopodobnie do czynienia z ingerencją w tekst, wynikającą z kształtu druku - tekst w tym rozdziale zapisano w postaci kolumny szpicowej (co również widać na fotografii).

De creatione: Quomodo Eva instante morte eius, convocavit omnes filios et dixit eis, ut scriberent vitam eorum et que audierunt et viderunt ab eis in tabulas lapideas, ne periret memoria primorum parentum ${ }^{7}$

Historyja barzo cudna: Jako Ewa, gdy miała przyść godzina śmierci jej, wezwała wszytkich synow i rzekła im, iżeby napisali żywot ich na tabliczkach kamiennych i co widzieli i słyszeli od nich, aby nie zaginęla pamiątka pierwszych rodziców

W pierwszym zdaniu składowym wyrażenie instante morte (pol. 'gdy dochodziła śmierć') Pussman przetłumaczył jako gdy miała przyjść godzina śmierci. Indeks haset Stownika polszczyzny XVI wieku notuje połączenia leksemów godzina i śmierć w wielu tekstach, również w apokryficznym $\dot{Z} y w o-$ cie Pana Jezu Krysta Baltazara Opeca (por. http://spxvi.edu.pl/indeks/haslo /53211\#znaczenie-8). Na podstawie przykładów zgromadzonych w słowniku

7 Aby oddać cechy typograficzne omawianych druków, wytłuszczono tytuły rozdziałów. 
można wnioskować, że w XVI wieku było to już stałe połączenie, chętnie wykorzystywane przez twórców tekstów religijnych, których jedną z cech są właśnie stałe połączenia wyrazowe.

De creatione Adae: Post multos vero dies, cognoscens Eva mortem suam, congregavit omnes filios et filias suos et dixit eis: Audite, filii mei carissimi, referam vobis: „Postquam ego et pater vester transgressi sumus mandata Dei, tunc dixit Michael Archangelus: «Propter prevaricationes vestras inducit Dominus iudicii iram super vos. Primum per aquam, secundum per ignem. In hiis ergo iudiciis duobus iudicabit Dominus genus humanum»". Audite ergo me, filii mei: faciatis vobis tabulas lapideas et alias de terra et scribatis vitam nostram et que de nobis audistis et vidistis, ne pereat memoria primorum parentum vestrorum in eternum.

Historyja barzo cudna: Po wielu tedy dni poznawszy Ewa godzinę śmierci swojej, zgromadziła wszystkie syny i dziewki swoje i rzekła im: Słuchajcie, synowie moi namilsi, powiem wam: „Gdym ja i ojciec wasz przestąpiliśmy przykazanie Boże, tedy rzekł Michał Anjoł: «Dla waszego przestąpienia przywiedzie Pan Bog sąd gniewu na was. Napierwej przez wodę, po wtore przez ogień. W tych to przeto sądziech dwu będzie Pan $B<$ og $>$ sądził rodzaj ludzki»". Słuchajcież mię tedy mili synowie: „Uczyńcie sobie tablice kamienne a drugie z ziemie, a wypiszcie żywot nasz i coście od nas słyszeli i widzieli, aby nie zginęła na wieki pamiątka pierwszych rodzicow waszych".

Grupę imienną Michael Archangelus Pussman przełożył jako Michał Anjoł. Słowo archangelus pojawiło się w tekście łacińskim po raz pierwszy, ale Pussman przełożył je tak, jak do tej pory tłumaczył wyraz angelus. Nieróżnicowanie nazwy mogło wynikać z automatyzmu tłumaczeniowego. Tym bardziej że Michał jest jedynym archaniołem występującym w tekście, a każdy archanioł jest jednocześnie aniołem.

De creatione Adae: Hec cum dixisset Eve $\mathrm{f}<\mathrm{i}>$ liis suis, expandit manus suas in celum, et gracias agens Deo, tradidit spiritum et sepelierunt eam filii et filie iuxta Adam, virum suum. Tunc autem factus est fletus magnus et fecerunt planctum magnum per xxx dies.

Historyja barzo cudna: Gdy to wyrzekła Ewa synom swym, wyciągnąwszy ręce swe w niebo, a dziękując $\mathrm{P}<\mathrm{anu}>\mathrm{Bogu}$, dała ducha swego w ręce jego i pogrzebli 
ją synowie i dziewki jej podle Adama, męża jej. Stał się tedy płacz wielki i uczy$\mathrm{n}<$.>ili wielki żal i narzekanie przez trzydzieści dni.

W powyższym fragmencie szczególnie interesujące jest to, że Pussman do wyrażenia tradidit spiritum (pol. dała ducha) dodał, najprawdopodobniej za Księgą Psalmów, frazę swego w ręce jego. Całe wypowiedzenie dała ducha swego $w$ ręce jego jest bardzo zbliżone do Ps 31 (30), 6: „W ręce twe polecam ducha mego $(. . .)^{8 "}$.

Słowo planctus przełożył jako żal i narzekanie. Wcześniej również oddawał go szeregami, ale innymi: „płacz i boleść” oraz „płacz i smutek wielki” (Stelmach 2020). Widać na tym przykładzie, że ten łaciński leksem mógł być bardzo różnie oddawany w polszczyźnie, a jego znaczenie było szerokie.

De creatione Adae: Postquam ita in luctu fuissent per vii dies, apparvit eis Michael et dixit ad Seth: „Homo Dei, non amplius lugetis mortuos vostros, quam per vi dies, cum in vi diebus Dominus omnia creavit et requrevit die vii ab opere suo. Octavus vero dies est future et eterne beatitudinis, in quo omnes boni cum ipso creatore et salvatore nostro sicut cum corpore et anima nunquam de cetero morientur, sed regnabunt per infinita secula seculorum. Amen". Vita Ade et Eve absoluta et feliciter.

Historyja barzo cudna: A gdy tak byli w wielkim żalu i płaczu, ukazał się im Anjoł Michał w siedmi dni i rzekł do Set, syna Adamowego: „Człowiecze Boży, już więcej nie płaczcie umarłych waszych, $<\mathrm{j}>$ edno przez sześć dni, gdy $\mathrm{P}<\mathrm{an}>\mathrm{Bog}$ przez dni sześć wszytko stworzył i dnia siodmego odpoczynął od wszelkiej sprawy swej, ktory to dzień Pan $\mathrm{B}<0>\mathrm{g}$ poświęcił i błogosławił. A osmy dzień jest przyszłego i wiecznego błogosławieństwa, w ktory wszyscy dobrzy z stworzycielem i zbawicielem naszym, to jest $\mathrm{z} \mathrm{P}<\mathrm{a}>$ nem Chrystusem, $\mathrm{z}$ ciałem i z duszą nigdy potym nie umrą, ale będą krolować na wiek wiekow. Amen."

Imię Michael Pussman znów przełożył z użyciem grupy imiennej Michał Anjot, a do imienia Seta dodał przydawkę przymiotną syn Adamowy. Tak regularne podkreślanie przynależności rodowej poszczególnych postaci może świadczyć o tym, że tłumacz chciał jak najdokładniej przybliżyć historię

${ }^{8}$ Cytat za: Biblia Jakuba Wujka, [online:] http://biblia-online.pl/Biblia/JakubaWuj$\mathrm{ka} /$ Ksiega-Psalmow/31/6 [dostęp: 29.04.2020]. 
grzechu pierworodnego ${ }^{9}-\mathrm{w}$ tym wypadku istotne były zależności między bohaterami, gdyż to dzieci dziedziczyły grzech po swoich rodzicach (na fakt dziedziczenia grzechu wskazywał m.in. Antoni Żurek [2016: 149]). Analiza zapisu imienia Seta (w całym tekście jest nieodmieniane) pokazuje również, że nie był on prawdopodobnie zbyt dobrze znany. Być może z tego właśnie względu tak często wskazywano na pokrewieństwo tego bohatera.

W dalszej części omawianego fragmentu tłumacz dodał również zdanie podrzędne przydawkowe ktory to dzień Pan Bog poświęcił i pobłogosławit, dookreślając siódmy dzień, jako nie tylko ten, w którym Pan Bóg „odpoczynął od wszelkiej sprawy swojej” (por. Celichowski 1890: 11; Stelmach 2020). Cytowane zdanie przydawkowe jest parafrazą biblijnego: Et benedixit diei septimo; et sanctificavit illum ${ }^{10}$, które Pussman przełożył dosłownie $\mathrm{w}$ drugim rozdziale swojego dzieła. Wprowadzenie parafrazy w końcowym fragmencie utworu może świadczyć o tym, że autor po pierwsze ogarniał całość kompozycji tekstu, wprowadzając intertekstualne nawiązania do własnego przekładu $^{11}$, a po drugie świadomie nawiązywał do tekstu Pisma Świętego, powołując się w ten sposób na jego autorytet.

Pominięte zostało natomiast ostatnie zdanie całego apokryfu: Vita Adae et Evae absoluta est feliciter (pol. 'Żywot Adama i Ewy szczęśliwie ukończony’). Wydawca De creatione Adae mógł taką frazę zamieścić jako zwieńczenie utworu, ponieważ najprawdopodobniej był to tekst wydany pojedynczo. Natomiast Historyja barzo cudna została wydana wraz z kilkoma wyimkami z Eklezjastyka, co przemawiało za tym, by powyższe wypowiedzenia opuścić. Istnieją przesłanki wskazujące na jeszcze inne powody, dla których to zdanie nie znalazło się w tekście.

Ponadto trzeba zwrócić w tym miejscu uwagę na tytuł utworu (Historia barzo cudna $i$ ku wiedzeniu potrzebna o stworzeniu nieba $i$ ziemie, $i$ inszych wszytkich rzeczy, ktore i żywa na świecie. I jako potym Pan Bog człowieka, to jest Jadama, i Jewę z kości jego stworzyl a jako żywota swego na tym świecie dokonali etc. teraz nowo na polskie z pilnościa wyłożona). Różni się on

9 Albo był przyzwyczajony do biblijnego sposobu opisu relacji między postaciami.

10 Cyt. za: Biblia łacińsko-polska, czyli Pismo Święte Starego i Nowego Testamentu. Podtug textu łacińskiego Wulgaty, i przekładu polskiego x. Jakóba Wujka T.J. z komentarzem Menochiusza T.J. przełożonym na język polski. Przedruk: Komorów 1997.

11 Warto przypomnieć, że początkowe rozdziały Księgi Rodzaju Pussman wkomponował w przekład XV-wiecznego wydania łacińskiego apokryfu. 
znacząco od tytułu łacińskiego, czyli De creatione Adae et formatione Evae ex costa eius. Et quomodo decepti fuerunt a serpente. Łaciński tytuł jest, można by powiedzieć, omowną konstrukcją w stosunku do pierwotnej nazwy tego apokryfu, czyli Vita Adae et Evae (więcej o tym tekście zob. Meyer 1879; Dobrzycki 1899; Stelmach 2020). Mógł więc wydawca tekstu pozostawić zdanie podsumowujące, gdyż apokryf łaciński faktycznie opowiadał żywot Adama i Ewy.

Staropolski tekst natomiast został uzupełniony o biblijną historię stworzenia świata, a dzieje życia pierwszych rodziców służyły dopełnieniu tej historii. Czytane osobno mogły być odbierane jako popularna opowiastka, choć analiza języka tego dzieła pokazuje, że równie dobrze tekst mógł być wykorzystywany w egzegezie lub katechezie dotyczącej grzechu pierworodnego (więcej na ten temat zob. Stelmach 2020).

Przeprowadzone analizy pozwalają wysnuć następujące wnioski dotyczące sposobu przekładu oraz języka tekstu z kodeksu BJ sygn. Cim.769:

1. W przekładzie są liczne miejsca, w których znajdują się zmiany wprowadzone przez Pussmana względem źródła. Tłumacz pomija poszczególne wyrazy, dodaje słowa, czasem również całe zdania, rozbudowując treści niesione przez źródło. Takie postępowanie tłumacza wskazuje na kompilacyjny charakter utworu - jest ono typowe na tle dzieł tłumaczonych w dobie staropolskiej i u progu średniopolskiej. Piszą o tym w swoich pracach m.in. Dorota Rojszczak-Robińska (2012), Tomasza Mika (2002), a także Mariusz Leńczuk (2016).

2. W całości utworu są uzupełnienia, które nie pochodzą z tekstu łacińskiego, ale ich charakter wskazuje na czerpanie przez Pussmana z Księgi Psalmów (por. s. 10 artykułu oraz Stelmach: 2020).

3. Tłumacz często dodaje zaimki. Robił to zwłaszcza we fragmentach dotyczących relacji między postaciami. Poświadczają to oba zachowane egzemplarze utworu.

4. Łacińska konstrukcja ablativus absolutus tłumaczona jest za pomocą zdań podrzędnych okolicznikowych.

5. Pussman stosuje połączenia wyrazowe w postaci synonimicznych szeregów składniowych, które są charakterystyczne dla stylu religijnego i średniowiecznych przekładów. Ich pochodzenie mogło być różne: pojawiały się z powodu wciągnięcia glos do tekstu głównego, ze względu 
na naśladowanie stylu biblijnego lub po prostu w wyniku implementowania zasad stylistyczno-retorycznych, będących podstawowym narzędziem w warsztacie pracy tłumacza (por. Lausberg 1998, Leńczuk 2015).

6. Między obu wydaniami staropolskimi występują różnice graficzne oraz typograficzne:

a) zapisywanie imion bez prejotacji w wyd. B (Adam zamiast Jadam, Ewa zamiast Jewa);

b) zapisywanie grupy spółgłoskowej „szcz” jako „scz”;

c) stosowanie kolumny szpicowej w wydaniu B.

7. W wyd. B widać znaczną liczbę elementów, które pierwotnie mogły znajdować się poza tekstem głównym (mieć postać glos). Wprowadzenie ich do druku zmieniło prawdopodobnie pierwotny kształt tekstu. Niektóre glosy są wielopoziomowe, w związku z czym tekst podstawowy (główny) staje się o wiele bardziej rozbudowany treściowo. Z drugiej strony ta wielopoziomowość prowadzi do zmiany relacji składniowych między elementami tekstu głównego. Niezgodność składniowo-fleksyjna poszczególnych fragmentów Historyi barzo cudnej pozwala wnioskować o ich pierwotnej budowie. Glosy mogły być również wynikiem dążenia średniowiecznych tłumaczy do wiernego przekładu z łaciny, przywołania możliwie wielu ekwiwalentów polskich dla przekładanego słowa obcego..

Obecność glos w tekście świadczy o tym, że tekst staropolski „żył” - był materiałem ciągle zmienianym, ulepszanym, poprawianym w taki sposób, by odpowiadał potrzebom odbiorców. Natomiast zbieżności zaobserwowane między obu wydaniami świadczą o tym, że są cechą stylistyczną tekstu i tłumacza, a nie konkretnego wydania. Pokazują też, że zapotrzebowanie na fabuły niekanoniczne z upływem wieków nie malało, zaś wcześniejszy przekład stał na wysokim poziomie, skoro modyfikowano go nieznacznie. 


\section{Bibliografia}

ADAMCZYк M., 1980, Biblijno-apokryficzne narracje w literaturze staropolskiej do końca XVI wieku, Poznań: Wydawnictwo UAM.

Biblia Jakuba Wujka, [online:] http://biblia-online.pl/Biblia/JakubaWujka/Ksiega-Psalmow/31/6 [dostęp: 29.04.2020].

Cały świat nie pomieściłby ksiag. Staropolskie opowieści i przekazy apokryficzne, 1996, W. R. Rzepka, W. Wydra (red.), M. Adamczyk (wstęp), Warszawa: PWN.

Celichowski Z., 1890, Krzysztofa Pussmana Historyja barzo cudna o stworzeniu nieba i ziemi, 1551, Kraków: Wydawnictwa Akademii Umiejętności.

CHOWAĆ [hasło], w: Stownik polszczyzny XVI wieku, M. R. Mayenowa (red.), t. 3, Wrocław: Ossolineum, s. 302.

De creatione Adae et formatione Evae ex costa eius. Et quomodo decepti fuerunt a serpente, 1487, S. Plannck (red.), Rzym (sygn. BJ St. Dr. Inc. 2654).

Dobrzycki S., 1899, Z dziejów średniowiecznego piśmiennictwa polskiego, Prace Filologiczne 5, s. 985-995.

DobrzycKi S., 1911, Z literatury apokryficznej w Polsce. 2. Historya barzo cudna o stworzeniu nieba i ziemie, Prace Filologiczne 7, s. 286-299.

GODZINA [hasło], w: Indeks haset Stownika polszczyzny XVI wieku, [online:] http:// spxvi.edu.pl/indeks/haslo/53211\#znaczenie-8 [dostęp: 29.04.2020].

Kleszczowa K., 2002, Bogactwo staropolskiej synonimii, w: I. Opacki (red.), Dzieto literackie i ksiażka w kulturze. Studia i szkice ofiarowane Profesor Renardzie Ocieczkowej w czterdziestolecie pracy naukowej i dydaktycznej, Katowice: Wydawnictwo Uniwersytetu Śląskiego, s. 279-287.

Kozaryn D., 2000a, Językowy obraz Judasza w staropolskich tekstach pasyjnych, Poznańskie Studia Polonistyczne. Seria Językoznawcza VIII, s. 104-116.

LeŃCZuK M., 2007, Synonimia w średniowiecznych przekładach kanonu mszy św. uwagi wstępne, Język Polski LXXXVII, s. 37-47.

LeŃcZuk M., 2013, Staropolskie przekazy kanonu Mszy Świętej. Wariantywność leksykalna, Warszawa: Wydawnictwo Instytutu Badań Literackich PAN.

LeŃczuk M., 2016, O sposobach tłumaczenia „Nowego Testamentu” w „Rozmyślaniu przemyskim”, w: J. Bartmiński, A. Timofiejew (red.), „Rozmyślanie przemyskie”. Świadectwo średniowiecznej kultury religijnej, Przemyśl: Państwowa Wyższa Szkoła Wschodnioeuropejska s. 123-131.

Luto-KamińsKa A., 2015, Znaczenie literatury Tatarów Wielkiego Księstwa Litewskiego dla badań lingwistycznych nad polskimi tekstami dawnymi, w: G. Czerwiński, A. Konopacki (red.), Estetyczne aspekty literatury polskich, biatoruskich i litewskich Tatarów (od XVI do XXI w.), Białystok: Alter Studio, s. 69-84. 
Meyer W., 1879, Vita Adae et Evae, Abhandlungen der Bayerischen Akademie der Wissenschaften, Philosophische-Philologische Klasse 14,3, München.

Mika T., 2002, Maryja, Jezus, Bóg w „Rozmyślaniu przemyskim”. O nazywaniu osób, (Biblioteczka Poznańskich Studiów Polonistycznych. Seria Językoznawcza, nr 17), Poznań: Wydawnictwo WIS.

POGRZEBIAĆ [hasło], w: Stownik polszczyzny XVI wieku, K. Wilczewska (red.), t. 26, Warszawa: Instytut Badań Literackich PAN, s. 126.

Pussman K., 1551, Historia barzo cudna $i$ ku wiedzeniu potrzebna o stworzeniu nieba i ziemie, i inszych wszytkich rzeczy, ktore i żywa na świecie. I jako potym Pan Bog czlowieka, to jest Jadama, i Jewę z kości jego stworzyl, a jako żywota swego na tym świecie dokonali etc. teraz nowo na polskie z pilnościa wytożona, Kraków: Hieronim Scharffenberg, [online:] https://www.wbc.poznan.pl/dlibra/publication/197296/edition/180776/content [dostęp: 30.05.2020].

Pussman K., b.r., Historia barzo cudna i ku wiedzeniu potrzebna o stworzeniu nieba i ziemie, i inszych wszytkich rzeczy, ktore i żywa na świecie. I jako potym Pan Bog czlowieka, to jest Jadama, i Jewę z kości jego stworzyl, a jako żywota swego na tym świecie dokonali etc. teraz nowo na polskie z pilnościa wytożona, Kraków: [online:] https://jbc.bj.uj.edu.pl/dlibra/publication/389512/edition/370373/ content [dostęp: 30.05.2020].

RoJszCZak-Robińska D., 2012, Jak pisano „Rozmyślanie przemyskie”, Poznań: Wydawnictwo Rys.

RoJszCZak-RobiŃska D., 2016, Staropolskie pasje. „Rozmyślanie przemyskie”, „Sprawa chędoga”, „Karta Rogawskiego”. Źródta- język-fabuła, Poznań: Wydawnictwo Rys.

Stowo Jana Złotoustego o tym, jak Michat zwyciężyt Satanaela, 2006, w: G. Minczew, M. Skowronek (red.), Apokryfy i legendy starotestamentowe Stowian Południowych, Kraków: Wydawnictwo Uniwersytetu Jagiellońskiego, s. 12-25.

Sondel J., 2003, Stownik łacińsko-polski dla prawników i historyków [CD-ROM], Kraków: Universitas.

Starowieyski M., 2006, Barwny świat apokryfów, Poznań: Drukarnia i Księgarnia Świętego Wojciecha.

Stelmach W., (2019), Historyja barzo cudna o stworzeniu nieba i ziemie Krzysztofa Pussmana - strategie tłumaczenia, Slavia Occidentalis 76/1, s. 119-135..

Stelmach W., (2020), Historyja barzo cudna wobec źródet. Przekład, kompilacja, dzieto, Lublin.

TwARDZIKowIE J. i W., 1976, Łaciński ablativus absolutus w polskich XV-wiecznych przektadach Biblii, w: S. Urbańczyk (red.), Studia z polskiej sktadni historycznej, t. 1, Wrocław: Wydawnictwo Polskiej Akademii Nauk, s. 41-69.

ZowCZAK M., 2013, Biblia ludowa. Interpretacje wątków biblijnych w kulturze ludowej, Toruń: Wydawnictwo Naukowe Uniwersytetu Mikołaja Kopernika. 
Żurek A., 2016, Ewa - pierwsza kobieta w świetle pism św. Augustyna, Vox Patrum 66, s. 139-153.

\section{The language of the text of the code in the collections of Jagiellonian Library (Cim. 769) ( s u m mary)}

The aim of the paper is to characterize the language of the text of a code from the collection of the Jagiellonian Library (Cim.769). The code includes the incomplete edition of Krzysztof Pussman's The Marvelous Story of the Heaven and Earth Creation, dated after 1551. The translation was analysed in a comparative way with its probable Latin source. The article presents the results of the linguistic analyses of the selected fragments of the edition, particular attention was given to the methods of text translation. This allowed to indicate the characteristics of the print, as well as relate them to some conclusions resulting from the work on the 1551 edition.

Ke y w o rd s: The Marvelous Story of the Heaven and Earth Creation; De creatione Adae et formatione Evae ex costa eius; old-Polish translation; apocrypha; Cim.769 